\title{
GAMBARAN STANDAR PERENCANAAN DAN PENGADAAN OBAT DI INSTALASI FARMASI RSU KOTA TANGERANG SELATAN TAHUN 2017
}

\author{
Nurwulan Adi Ismaya, Tri Okta Ratnaningtyas, Rani Riskha Wahyuni \\ Sekolah Tinggi Ilmu Kesehatan Kharisma Persada \\ Tangerang Selatan, 15417 \\ E-mail:wulan.ismaya@gmail.com
}

\begin{abstract}
ABSTRAK
Perencanaan dan pengadaan merupakan aspek terpenting dalam pengelolaan obat dan hal pertama yang dilakukan agar menghindari kekosongan obat. Tujuan Penelitian ini adalah untuk mengetahui kefesienan dan keefektifan pengelolaan obat pada tahap Selection dan Procurement di Rumah Sakit Umum Kota Tangerang Selatan tahun 2017. Penelitian menggunakan rancangan penelitian deskriptif dengan pengambilan data secara retrospectif. Data berupa kualitatif dan kuantitatif disertai wawancara pada pihak terkait. Tahap Selection dan Procurement di ukur efesiensinya dengan menggunakan indikator yang dikeluarakan oleh Depkes RI (2002). Hasil penelitian diperoleh bahwa pada tahap selection Pengelolaan obat di Rumah Sakit Umum Kota Tangerang Selatan pada tahun 2017 menunjukan hasil yang belum efektif, dilihat dari hasil pengukuran pada indikator kesesuaian item obat dengan DOEN menunjukan hasil nilai sebesar 20,90\% dibawah nilai standarnya yaitu 49\%. Kemudian pada tahap Procurement menunjukan hasil yang efektif, yaitu pada indikator Frekuensi pengadaan item obat pertahun menunjukan hasil frekuensi sebanyak 1-19x/tahun (Standar sedang), indikator frekuensi kesalahan faktur/surat pesanan sebanyak 2 kali dari nilai pembanding 1-9 kali, dan indikator frekuensi tertundanya pembayaran oleh pihak rumah sakit sebanyak 15 kali dari nilai pembanding 025 kali. Procurement obat di RSU kota Tangerang Selatan dikatakan sudah efektif dilihat dari indikator Frekuensi pengadaan item obat pertahun, frekuensi kesalahan faktur/surat pesanan, dan frekuensi tertundanya pembayaran oleh pihak rumah sakit. Berdasarkan hasil penelitian ini, pengadaan (procurement) di RSU kota Tangerang Selatan sudah efektif, tetapi seleksi (selection) obat di RSU Kota Tangerang Selatan belum efektif.
\end{abstract}

Kata kunci : Pengelolaan obat, Manajemen Farmasi, Pudjaningsih

\begin{abstract}
Selection and Procurement are the crucial things in drug management system and they become primary things to do to avoid drug emptiness. The objective oh this research is to know the effectiveness and effeciency of drug management in Selection and Procurement stage at South Tangerang City General Hospital in 2017. The methods of this research is descriptive research design with retrospective data retrieval. Data in the form of qualitative and quantitative accompanied by interviews with related parties. Selection and Procurement Phase in the measurement of its efficiency by using the indicator that issued by MOH RI (2002). The results showed that in the selection stage of drug management at Tangerang Selatan Public Hospital in 2017 showed it has not been effective, it has seen from the measurement on the indicator of conformity of the drug item with the DOEN showed the value of $20.90 \%$ below the standard value of $49 \%$. Then at the Procurement stage showed effective results, it has seen from the Frequency of procurement of medicinal items each year showed frequency results as much as 1-19x / year (Medium standard), the frequency of error invoice / order letter as much as 2 times the value of comparison 1-9 times, and the frequency of delayed payment by the hospital 15 times from the comparison value 0-25 times. Drug procurement in South Tangerang General Hospital has been effective, it showed from the Frequency of procurement of medicinal items per year, the frequency of error invoice / order letter, and the frequency of delayed payment by the hospital. Based on this results, the Drug Procurement in South Tangerang General Hospital has been effective, but the selection hasn't effective yet.
\end{abstract}

Keywords : Drug Management, Pharmacy Management, Pudjaningsih 


\section{PENDAHULUAN}

Pengelolaan perbekalan farmasi atau manajemen sistem perbekalan farmasi merupakan suatu siklus kegiatan yang dimulai dari perencanaan sampai evaluasi yang saling terkait antara satu dengan yang lain. Proses perencanaan obat memiliki beberapa tahapan yaitu tahapan pemilihan, kompilasi penggunaan, perhitungan kebutuhan dan evaluasi perencanaan (Direktorat Jendral Pengawasan Obat dan Maknan tahun 1990). Pemilihan obat di rumah sakit merujuk kepada Daftar Obat Esensial Nasional (DOEN) sesuai dengan kelas rumah sakit masing-masing, Formularium RS, Formularium Jaminan Kesehatan bagi masyarakat miskin, Daftar Plafon Harga Obat (DPHO) akses dan Jaminan Sosial Tenaga Kerja (JAMSOSTEK). Pengelolaan obat terutama pada tahap perencanaan dan pengadaan di rumah sakit merupakan salah satu aspek penting dari rumah sakit. Tujuan pengelolaan obat adalah tersedianya obat setiap saat dibutuhkan baik mengenai jenis, jumlah maupun kualitas secara efisien.

Menurut American Hospital Associaton pada tahun 2011, 99,5\% rumah sakit di negara tersebut mengalami kekurangan obat dalam periode enam bulan yaitu pada bulan Januari-Juni. Lalu, $82 \%$ rumah sakit menunda perawatan pasien akibat kekurangan obat dan lebih dari setengahnya tidak mampu menyediakan obat sesuai dengan resep yang diberikan. Selain itu, biaya obat pun meningkat akibat dari kekurangan obat. Ketidakefektifan dan ketidakefisienan pengelolaan dalam bidang penyediaan obat menjadikan pengadaan obat di rumah sakit tersebut mengalami kekurangan.

Berdasarkan hasil penelitian menurut Hastrana (2016) dalam penelitiannya yang berjudul Gambaran Pengelolaan Persediaan Obat di Instalasi Farmasi Rumah Sakit Umum Daerah (RSUD) Kabupaten Muna mengatakan bahwa persediaan obat di IFRS tersebut belum efektif dan efisien karena masih banyak ditemukan obat yang kosong seperti evedsin injeksi, oksitosine. Hal ini terlihat dari data bulan Januari-Desember tahun 2015 terdapat 36 dari 395 (3,95\%) jenis obat yang kadaluarsa atau rusak, serta ada $10 \%$ dari $395(3,95 \%)$ jenis obat yang mengalami kekosongan sehingga mengharuskan pasien untuk membeli obat di luar apotek Rumah Sakit Umum Daerah Kabupaten Muna, dan ditemukan juga obat yang sering kosong padahal tingkat permintaan obat berdasarkan jenis penyakit yang ada di Rumah Sakit Umum Daerah (RSUD) Kabupaten Muna cukup tinggi. 
Quick dkk (1997) menyebutkan bahwa siklus pengelolaan obat meliputi empat fungsi dasar, yaitu seleksi (Selection), perencanaan dan pengadaan (Procurement), distribusi (Distribution), dan penggunaan (Use) yang memerlukan dukungan dari organisasi (Organization), ketersediaan pendanaan (Financing sustainability), pengelolaan informasi (Information management) dan pengembangan sumber daya manusia (Human resources management) yang ada di dalamnya. Mengingat ketidak efisienan dan ketidak lancaran pengelolaan tersebut dapat memberi dampak negatif terhadap rumah sakit, maka Departemen Kesehatan RI dalam Pedoman Supervisi dan Evaluasi Obat Publik dan Perbekalan Kesehatan (2002), Pudjaningsih (1996), dan WHO (1993) menetapkan beberapa indikator pengelolaan obat yang dapat dikatakan memiliki nilai yang efisien dan efektif bila memenuhi dalam perhitungan.

Rumah Sakit Umum Kota Tangerang Selatan merupakan rumah sakit pemerintah yang berada di wilayah Tangerang Selatan dan merupakan rumah sakit tipe $\mathrm{C}$ yang memiliki visi "Menjadi Rumah Sakit pilihan yang bermutu dan amanah (Aman, Nyaman, Mandiri, Ramah) serta mewujudkan Tangerang Selatan sebagai Kota cerdas, berkualitas dan berdaya saing berbasis teknologi dan inovasi". Berdasarkan hasil wawancara penulis dengan kepala Instalasi Farmasi Rumah Sakit Umum Kota Tangerang Selatan, Masalah kekosongan obat merupakan masalah yang sering dialami oleh setiap rumah sakit begitupun dialami oleh Rumah Sakit Umum Kota Tangerang Selatan. Obat-obat yang sering mengalami kekosongan di Instalasi Farmasi Rumah Sakit Umum Kota Tangerang Selatan adalah jenis obatobatan emergency. Akibatnya untuk memenuhi kekosongan obat tersebut pihak rumah sakit memesan obat pada apotek lain di luar Rumah Sakit. Selain itu dalam meunjang proses perencanaan dan pengadaan obat, rumah sakit masih belum memiliki sistem yang sepenuhnya terintegrasi.

Berdasarkan latar belakang tersebut, penulis tertarik untuk mengetahui gambaran standar perencanaan dan pengadaan obat $d$ Instalasi Farmasi RSUD Kota Tangerang Selatan tahun 2017.

\section{METODE}

Penelitian ini merupakan jenis penelitian deskriptif dengan pengambilan data secara retrospektif yaitu pengambilan data yang sudah ada pada tahun sebelumnya atau pada masa lampau. Instrumen penelitian ini menggunakan 
lembar observasi, DOEN, daftar

tertentu. Dalam penelitian ini yang pengadaan obat tahun 2017 di RSU Kota Tangerang Selatan, daftar pemesanan obat, faktur, dan lembar wawancara. Metode sampling yang digunakan untuk menentukan sampel pada objek peneltian yaitu menggunakan non probability sampling dengan metode total sampling, kemudian untuk subjek penelitian yaitu menggunakan metode purposive sampling yaitu pengambilan sampel secara sengaja sesuai dengan persyaratan sampel yang di menjadi objek penelitian adalah seluruh daftar obat yang diadakan di udang farmasi RSU Kota Tangerang Selatan tahun 2017 dan yang menjadi subjek penelitian adalah kepala instalasi farmasi dan bagain bidang penunjnag medis yang dimintai wawancara terkait penelitian. Kemudian data yang sudah di kumpulkan di hitung dan dibandingkan dengan nilai pembanding pada masing-masing indikator.

perlukan karena ada pertimbangan

Tabel 2.1 Indikator Efisiensi Pengolaan Obat Di Rumah Sakit

\begin{tabular}{|c|c|c|c|}
\hline Tahapan & Indikator & Tujuan & Nilai pembanding \\
\hline Selection & $\begin{array}{l}\text { Kesesuaian item obat } \\
\text { denganDOEN } \\
\text { (DepKes RI,2002). }\end{array}$ & $\begin{array}{l}\text { Untuk mengetahui } \\
\text { penggunaan obat } \\
\text { esensial. }\end{array}$ & $\begin{array}{l}49 \% \\
\text { (DepKesRI,2002). }\end{array}$ \\
\hline \multirow{3}{*}{ Procurement } & $\begin{array}{l}\text { 1. Frekuensi } \\
\text { pengadaan item obat } \\
\text { pertahun } \\
\text { (Pudjaningsih,1996) }\end{array}$ & $\begin{array}{l}\text { Untuk mengetahui } \\
\text { berapa kali obat- } \\
\text { obat tersebut } \\
\text { dipesan dalam } \\
\text { setahun. }\end{array}$ & $\begin{array}{l}\text { Rendah }<12 \mathrm{x} / \text { tahun } \\
\text { Sedang } 12-24 \mathrm{x} / \text { tahun } \\
\text { Tinggi }>24 \mathrm{x} / \text { tahun } \\
\text { (Pudjaningsih,1996) }\end{array}$ \\
\hline & $\begin{array}{l}\text { 2. Frekuensi kurang } \\
\text { lengkapnya surat } \\
\text { pesanan } \\
\text { (Pudjaningsih,1996) }\end{array}$ & $\begin{array}{l}\text { Untuk mengetahui } \\
\text { berapa kali terjadi } \\
\text { kesalahan faktur }\end{array}$ & $\begin{array}{l}\text { 1-9 kali } \\
\text { (Pudjaningsih,1996) }\end{array}$ \\
\hline & $\begin{array}{l}\text { 3. Frekuensi } \\
\text { tertundanya } \\
\text { pembayaran oleh } \\
\text { rumah sakit terhadap } \\
\text { waktu yang } \\
\text { disepakati } \\
\text { (Pudjaningsih,1996) }\end{array}$ & $\begin{array}{l}\text { Untuk mengetahui } \\
\text { kualitas } \\
\text { pembayaran rumah } \\
\text { sakit. }\end{array}$ & $\begin{array}{l}\text { 0-25 kali } \\
\text { (Pudjaningsih,1996) }\end{array}$ \\
\hline
\end{tabular}

\section{HASIL}

\section{Selection (Kesesuaian Item Obat dengan DOEN)}

Pada tabel 2 diperoleh dari 507 item obat yang diadakan selama tahun 2017, yang disesuaikan dengan item obat yang berada di DOEN (Daftar obat esensial nasional). Bertujuan 
untuk mengetahui tingkat penggunaan

obat esensial.

Tabel 2. Hasil Penelitian Tahap Selection(Kesesuain item obat dengan DOEN)

\begin{tabular}{lcc}
\multicolumn{1}{c}{ Indikator } & Nilai Pembanding & Hasil \\
\hline $\begin{array}{l}\text { Kesesuaian item obat dengan } \\
\text { DOEN }\end{array}$ & $49 \%$ & $20,90 \%$ \\
\end{tabular}

Berdasarkan Tabel 2. kesesuaian tahun pada tahun 2017 dengan item obat item obat yang diadakan di instalasi yang berada di DOEN menunjukan nilai farmasi RSUK Tangerang Selatan selama persentase kesesuaian sebesar $20,90 \%$.

\section{Procurement}

a. Frekuensi Pengadaan Item Obat Pertahun.

Pada tabel 3 diperoleh dari tahun. Bertujuan untuk mengetahui berapa kali obat-obat tersebut dipesan dalam setahun.

507 item obat yang diadakan selama tahun 2017, diamati frekuensi pengadaan tiap item obat selama satu

Tabel 3. Hasil Penelitian Tahap Procurement (Frekuensi Pengadaan Item obat per-

\begin{tabular}{|c|c|c|}
\hline & ahun) & \\
\hline Indikator & Nilai Pembanding & Hasil \\
\hline \multirow{4}{*}{$\begin{array}{l}\text { Frekuensi pengadaan item obat per } \\
\text { tahun }\end{array}$} & Rendah $<12 x /$ tahun & 1-19x/tahun \\
\hline & Sedang & \\
\hline & $24 \mathrm{x} /$ tahun & \\
\hline & Tinggi $>24 \mathrm{x} /$ tahun & \\
\hline
\end{tabular}

Berdasarkan Tabel 3. frekuensi RSUK Tangerang Selatan pada pengadaan item obat pertahun yang tahun 2017 sebanyak 1-19x/ tahun. diadakan di instalasi farmasi

b. Frekuensi Kurang lengkapnya Surat Pesanan/kontrak.

Pada tabel 4 diperoleh dari 223 surat pesanan obat yang diadakan selama tahun 2017, diamati frekuensi kurang lengkapnya surat pesanan/kontrak. Bertujuan untuk mengetahui berapa kali terjadinya kesalahan faktur.

Tabel 4. Hasil Penelitian Tahap Procurement (Frekuensi Kurang Lengkapnya Surat Pesanan/Kontrak)

\begin{tabular}{ccc}
\hline Indikator & Nilai Pembanding & Hasil \\
\hline Frekuensi kurang lengkapnya surat & $1-9$ kali & 2 kali \\
\hline
\end{tabular}


Berdasarkan Tabel 4.

frekuensi kurang lengkapnya surat pesanan/kontrak di instalasi

c. Frekuensi Tertundanya

Pembayaran Oleh Rumah Sakit

Terhadap Waktu yang Ditentukan.

Pada tabel 5. diperoleh dari hasil wawancara mendalam mengenai pembayaran rumah sakit farmasi RSUK Tangerang selatan selama tahun 2017 terjadi sebanyak 2 kali.

Tabel 5. Hasil Penelitian Tahap Procurement (Frekuensi Tertundanya Pembayaran Oleh Rumah Sakit Terhadap Waktu Yang di Tentukan)

\begin{tabular}{lcc}
\hline \multicolumn{1}{c}{ Indikator } & Nilai Pembanding & Hasil \\
\hline $\begin{array}{l}\text { Frekuensi tertundanya pembayaran oleh } \\
\text { Rumah sakit terhadap waktu yang } \\
\text { ditentukan }\end{array}$ & $0-25 \mathrm{kali}$ & $15 \mathrm{Kali}$ \\
\hline
\end{tabular}

$\begin{array}{rll}\text { Berdasarkan } & \text { Tabel 5. } & \text { yang ditentukan selama tahun } \\ \text { frekuensi tertunda } & \text { pembayaran } & 2017 \text { sebanyak } 15 \text { kali. }\end{array}$

oleh rumah sakit terhadap waktu

\section{DISKUSI}

1. Tahap Seleksi

Pengukuran persentase kesesuaian item obat yang tersedia dengan DOEN pada daftar obat yang diadakan gudang farmasi pada tahun 2017 sebesar 20,90\%. Jumlah item obat yang diadakan di IFRS sebanyak 507 item obat. Menurut Departemen Kesehatan bahwa nilai standar untuk indikator kesesuaian item obat yang tersedia dengan DOEN adalah sebesar terhadap waktu yang ditentukan. Bertujuan untuk mengetahui kualitas pembayaran rumah sakit. 
bahwa untuk pengadaan obat lebih besar mengacu pada daftar obat di $e$ -

\section{Tahap Procurement}

a. Frekuensi Pengadaan Item Obat Pertahun.

Frekuensi pengadaan item obat pertahun dapat digolongkan menjadi tiga kategori yaitu frekuensi rendah (<12), sedang (12-24), dan tinggi (>24), banyaknya obat dengan frekuensi sedang dan tinggi menunjukan kemampuan IFRS dalam merespon perubahan kebutuhan obat dan melakukan pembelian obat dalam jumlah sesuai deegan kebutuhan saat itu. Pengadaan obat yang berulang juga menunjukan bahwa yang tersedia di IFRS merupakan obat dengan perputaran cepat (fast moving). Banyaknya obat yang masuk kedalam jenis (slow moving) dapat berarti kerugian bagi rumah sakit . Cara analisisnya yaitu dengan mengambil secara acak sejumlah kartu stok dalam setahun, dicatat nama masing-masing obat. Kemudian di lihat pada catatan pengadaan selama tahun tersebut.

Dari hasil data frekuensi pengadaan item obat di RSU Kota Tangerang Selatan menunjukan bahwa pada tahun 2017, frekuensi pengadaan item obat pertahun sebanyak 1-19 kali. Menurut catalog.

penelitian Pudjaningsih (1996) nilai ini masuk ke dalam kategori standar sedang (12-24 x/tahun). Dari hasil wawancara dengan kepala IFRS, pengadaan obat dilakukan selama satu tahun sekali melalui pelelangan dan setiap bulan dengan cara pemesanan melalui e-catalog.

Dari hasil penelitian didapatkan bahwa nilai persentase yang dikeluarkan untuk pemesanan dari sumber APBD melalui lelang dan e-catalog berturut-turut adalah $22,29 \%, \quad 38,6 \%$. Jika kedua persentase ini dijumlah maka didapati hasil persentase pemesanan item obat melalui sumber anggaran APBD sebesar $\quad 60,89 \%$. Sedangkan persentase pemesanan item obat yang bersumber dari anggaran BLUD sebesar 39\%.

Pengadaan melalui pelelangan dan e-catalog bersumber pada anggaran APBD

(Anggaran Pendapatan dan Belanja Daerah) yang memiliki dana lebih besar dibandingkan anggaran BLUD (Badan Layanan Umum Daerah). 
b. Frekuensi Kurang Lengkapnya Surat Pesanan/Kontrak

Kriteria kesalahan faktur pembelian yang digunakan adalah adanya ketidak cocokan jenis obat, jumlah obat dalam suatu item, atau jenis obat dalam faktur terhadap surat pesanan yang bersesuaian. Cara analisinya adalah dengan mengambil secara acak sejumlah faktur tersebut dicocokan dengan surat pesanan, ketidakseusian faktur dengan surat pesanan.

\section{c. Frekuensi}

Tertundanya

Pembayaran Oleh Rumah Sakit

Terhadap Waktu yang Ditentukan.

Tingkat frekuensi tertundanya pembayaran menunjukan kurang baiknya manajeman keuangan pihak rumah sakit. Hal ini dapat menunjukan keperkayaan pihak pemasok kepada rumah sakit sehingga potensial menyebabkan ketidaklancaran suplai obat dikemudian hari.

Hasil penelitian frekuensi tertundanya pembayaran oleh Rumah Sakit Umum Kota Tangerang Selatran tahun 2017 terhadap waktu yang ditentukan menunjukan bahwa terjadi 15 kali tertundanya pembayaran.
Dari hasil pengamatan pada 223 sampel surat pesanan ditemukan terjadi ketidak-lengkapan sebanyak 2 kali sedangkan pengamatan faktur terjadi kesalahan sebanyak 6 kali. Ketidaksamaan jumlah ini terjadi karena adanya kesalahan faktur yang terjadi akibat pihak ketiga. Jika dibandingkan dengan penelitian Pudjaningsih (1996) nilai ini masih masuk dalam kategori efektif (1-9 kali).

Menurut penelitian Pudjanngsih (1996) nilai ini masuk kedalam katogori efektif. Menurut penelitian Pudjanngsih (1996) nilai ini masuk kedalam katogori efektif. Dari hasil wawancara dengan bagian bidang penunjang medis mengatakan bahwa pembayaran untuk belanja obat ditentukan sesuai dengan surat kontrak yang telah ditentukan.

Jatuh tempo untuk pembayaran selama 60 hari. Paling cepat pihak rumah sakit membayarnya 14 hari sebelum jatuh tempo. Sedangkan paling lambat pembayaran terjadi 7 
hari setelah jatuh tempo. Hal ini dikarenakan adanya kendala dari pihak ketiga seperti contoh kurangnya kelengkapan pada berkas-berkas yang mengharuskan untuk menunda pembayaran.

\section{SIMPULAN}

Berdasarkan hasil penelitian dari 507 item obat terkait tentang standar perencanaan dan pengadaan di Instalasi Farmasi RSUK Tangerang selatan tahun 2017 dapat disimpulkan :

1. Pada tahap selection, nilai kesesuaian item obat yang tersedia dengan DOEN menunjukan hasil yang belum efesien yaitu bernilai $20,90 \%$.

2. Pada tahap procurument hampir keseluruhan menunjukan hasil yang efesien: a. Jumlah frekuensi pengadaan item obat per tahun tergolong sedang yaitu 1-19 kali/tahun.

b. Jumlah frekuensi kurang lengkapnya surat pesanan/ kontrak menunjukan hasil yang sudah efesien yaitu 2 kali.

c. Jumlah frekuensi tertundanya pembayaran oleh rumah sakit terhadap waktu yang ditentukan menunjukan hasil yang sudah efesien yaitu sebanyak 15 kali.

\section{DAFTAR PUSTAKA}

Badaruddin, Mahmud, 2015, Gambaran Pengelolaan Persediaan Obat di Gudang Farmasi Rumah Sakit Umum Daerah Kota Sekayu Kabupaten Musi Banyu Asin Palembang Tahun 2015. Skripsi. FKIK UIN. Jakarta.

Departemen Kesehatan RI, 2002, Pedoman Supervisi Dan Evaluasi Obat Publik dan Perbekalan Kesehatan, Direktorat Bina Obat Publik dan Perbekalan Kesehatan, 8-15, Direktorat Jenderal pelayanan Kefarmasian dan Alat Kesehatan, Departemen Kesehatan RI, Jakarta. Departemen Kesehatan RI, Japan Internasional Cooperation Agency,
2010, Pedoman Pengelolaan Perbekalan Farmasu Di Rumah Sakit, 7-43, Direktorat Jendarl Bindakefarmasian dan Alat Kesehatan, Departemen Kesehatan RI, Jakarta.

Dirjen POM, 2002. Pedoman Perencanaan dan Pengelolaan Obat. Depkes RI. Jakarta Hudyono, J., dan Andayaningsih, 1990, Studi Pengelolaan Obat dan Sumber Daya Manusia, 15, Direktorat Jendral Pengawasan Obat dan Makanan,

Departemen Kesehatan Republik Indonesia, Jakarta. 
Hastrana, 2016, Gambaran Pengelolaan Persediaan Obat di Instalasi Farmasi Rumah Sakit Umum Daerah Kabupaten Muna, Sulawesi Tenggara.

Kementrian Kesehatan RI. 2009. UndangUndang Repbulik Indonesia Nomor 44 Tahun 2009 Tentang Rumah Sakit. Jakarta

Keputusan Menteri Kesehatan Nomor 1197/MENKES/SK/X/2004 tentang Standar Pelayanan Farmasi di Rumah Sakit/Peraturan Menteri Kesehatan RI Nomor 58 tahun 2014 tentang Standar Pelayanan Kefarmasian di Rumah Sakit.

Pudjaningsih, D., 1996, Pengembangan Indikator Efesiensi Pengelolaan Obat di Farmasi RS, Tesis, 40, Program Pasca Sarjana, Fakultas Kedokteran, Universitas Gadjah Mada, Yogjakarta.

Putri Ayu Lestari, Junaid, dan Lisnawaty, 2016, Analisis Pengendalian
Persediaan Obat Berdasarkan Metode Analisis ABC Indeks Kritis di Instalasi Farmasi Rumah Sakit Umum Daerah Kota Baubau Tahun 2016. Fakultas Kesehatan Masyarakat. Universitas Halu Oleo.Kendari, Sulawesi Tenggara

Siregar, C.J.P., dan Amalia,L., 2003, Farmasi Rumah Sakit, Teori Dan Penerapan, 7, Penerbit Buku Kedokteran EGC, Jakarta.

Qiuck, J.D., Rankin, J.R.,Laing, R.O., O’Connor, R.W., Hogerzeil, H.V., Dukes, M.N.G., Garnett, A., 1997, Managing Drug Supply, Second Edition, revised and

expanded, 4,14, 33, Kumarian Press, West Harford.

World Health Organization., 1993, How to Investigate Drug Use in Health Facilities, Selected Drugh Use Indicator, Action Program on Essential Drug, 46 52, WHO, Geneva. 